\title{
International corporate governance: introduction and overview
}

\section{Christine A. Mallin}

Corporate governance has become a global phenomenon. The financial scandals and collapses which have hit almost every country without exception have ensured that interest continues to grow unabated. Countries around the globe are either developing corporate governance codes or guidelines, or revamping those that they already have in existence. Global governance principles such as the OECD principles, originally issued in 1999, have been amended to take into account developments in the corporate governance arena and the revised OECD principles introduced in 2004.

Debate continues around such issues as whether boards should be accountable to wider stakeholder groups and, if so, who these groups are; the remuneration of directors; the role of institutional investors; the relationship between the company and its auditors, and many other areas. However certain common core themes have begun to emerge and these include the important role that can be played by independent non-executive directors; the appropriateness of key board sub-committees, including the audit committee and the remuneration committee. There is also a growing awareness that companies cannot operate in isolation from the wider society in which they are located, and that they need to consider the interests of groups other than shareholders if their longer term sustainability is to be maintained.

The purpose of this volume is to highlight, through various case studies, how corporate governance has evolved in a number of countries around the world and to illustrate its application in specific case study companies. The volume has four parts which focus on different regions and encompass different legal structures (civil law versus common law); different ownership structures; and differing governance structures.

\section{CORPORATE GOVERNANCE IN EUROPE}

Part 1 focuses on corporate governance in various European countries.

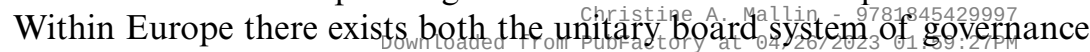


Corporate governance is still very much an emergent political issue in both Russia and Poland and therefore in both cases the authors of the two chapters have either used fictitious companies but drawn heavily on real life data or changed the companies' names, both for their own protection and for that of the companies.

\section{CORPORATE GOVERNANCE IN SOUTH EAST ASIA}

In this section, the range of corporate governance practices in South East Asia is clearly identified. The financial crisis of 1997 affected many of the so-called 'tiger economies', including Singapore (although it was not hit as badly as some of its neighbours), whilst Japan has experienced the bursting of its own economic bubble in recent years, at the same time as China's economy has been marching towards a socialist market economy.

Martin Conyon's chapter focuses on Singapore and the case of Singapore Technologies Engineering (ST Engineering), a company which has very high levels of transparency and disclosure. Singapore utilizes a unitary board structure, although it has significant state ownership of firms as well as the presence of other large blockholders. Effective ownership operates through a pyramid structure.

The next chapter in this part is by Guy Liu and Pei Sun and uses the example of Kelon to illustrate the evolution of ownership structure and governance process in China.

In the context of Japan, Megumi Suto and Motomi Hashimoto discuss corporate governance developments in Japan, highlighting the changes that have affected Japanese companies in the 1990s. They compare and contrast two 'giants' in Japan, Toyota and Sony, and show the contrasts in their governance styles.

\section{CORPORATE GOVERNANCE: ADDITIONAL DIMENSIONS}

The final part contains case studies from two countries: Turkey and South Africa. Melsa Ararat, Burcu Sener and Esin Taboglu have written an interesting case based on the fictional company v-Net (again political constraints warrant the use of a fictional case which draws on the personal knowledge of the authors). They show the types of problems that might

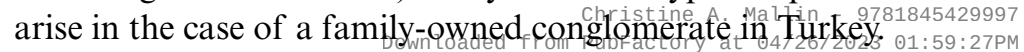


The final case by Reuel J. Khoza and Mohamed Adam details the evolution of governance in state-owned enterprises in South Africa, using the case of ESKOM to illustrate this. South Africa's corporate governance code is one of the most comprehensive, if not the most comprehensive, in the world. It embraces an inclusive approach taking account of various stakeholders' needs. This final case clearly shows how the adoption of the code impacts on the development of corporate governance in South African companies.

\section{CONCLUSIONS}

This volume contains case studies from many different regions around the globe, reflecting various ownership structures, legal systems, political and cultural aspirations. The development of corporate governance is at different stages in different countries, although all seem to value the core concepts of corporate governance including transparency and disclosure, and the benefits that good corporate governance can bring to both individual companies and to countries as a whole.

I would like to thank the authors for their time in writing the case studies. The authors, like the countries represented in the book, constitute a range of nationalities, and are from various professional backgrounds including academics, lawyers and company directors. What they have in common is an enthusiastic interest in corporate governance and how that is shaping the companies and the countries they have written about. I trust that readers of this volume will enjoy the various chapters and that new generations of students will in turn be enthused with the concept of corporate governance and become aware of the many benefits it can bring. 